\title{
Opettajien kokemuksia työn tuunaamisesta koira-avusteisen pedagogiikan avulla
}

\author{
Tarkastelussa työn vaatimukset, \\ työn voimavarat ja hyvinvointi työssä
}

\begin{abstract}
$y$
Työyhteisöissä tulisi suhtautua ennakkoluulottomasti työn tuunaamiseen, sillä se voi merkittävästi lisätä työntekijän hyvinvointia. Yksi tapa tuunata opettajan työtä on koira-avusteinen pedagogiikka. Haastatteluaineistoon

perustuva tutkimus osoittaa, että työn suunnittelu vaati aiempaa enemmän aikaa, mutta koiran läsnäolo luokassa paransi ilmapiiriä, mikä lisäsi hyvinvointia. Tuunaamisen reunaehdot ja sen vaikutukset sidosryhmiin tulee kuitenkin selvittää ennalta.
\end{abstract}

\section{$\mathbf{y}$}

OSAAMISEN UUDISTAMINEN ja ammattitaidon kehittäminen ovat välttämättömiä muuttuvassa työelämässä. Aikuisiällä osaamista voi kehittää esimerkiksi omaksumalla uusia, itseä kiinnostavia ja mielekkäitä työn tekemisen tapoja (Poell ym. 2004). Työn tuunaaminen on yksi tapa kehittää työtä. Sillä tarkoitetaan työntekijän aktiivista toimintaa, jolla omaa työtä muutetaan itselle mielekkäämmäksi (Tims \& Bakker 2010; van Wingerden ym. 2017). Työtehtävien ja työskentelytavan muuttaminen on yksi keskeinen työn tuunaamisen muoto (Lazazzara ym. 2019).
Tuunaamisella voidaan pyrkiä vähentämään työn vaatimuksia ja lisäämään sen voimavaratekijöitä, joilla puolestaan on osoitettu olevan yhteys työntekijän hyvinvointiin ja työssä suoriutumiseen (Peral 2016; van den Heuvel ym. 2015). Opettajat ovat yksi ammattiryhmä, jossa työn on havaittu olevan kuormittavaa (Hakanen ym. 2006; Soini ym. 2008). Työn kehittäminen työntekijän intressi- ja vahvuusalueiden suuntaisesti on tärkeää opettajien työssä jaksamiselle (Peral 2016; van Wingerden ym. 2017).

Eläinavusteiset työmuodot ovat 2010-luvulta lähtien yleistyneet useilla aloilla. Esimerkistä käy koira- 


\section{ELÄINAVUSTEISESTA TYÖST $\ddot{A}$}

\section{ON TULLUT SUOSITTUA}

\section{NIMENOMAAN OPETUKSESSA}

JA KASVATUKSESSA.

avusteinen toiminta. Suomessa koirat ovat mukana työtehtävissä muun muassa koulukoirina eri kouluasteilla, psyko- ja fysioterapian tukena ja sosiaalityössä (Kahilaniemi 2016). Eläinavusteisesta työstä on tullut suosittua nimenomaan opetuksessa ja kasvatuksessa (Correale ym. 2017; Cunha ym. 2019). Eläinavusteinen pedagogiikka on määritelty tavoitteelliseksi, suunnitelmalliseksi ja strukturoituja toimintatapoja sisältäväksi toiminnaksi, jota opetusalan ammattilaiset tai opetusalaa koskevien palveluiden ammattilaiset toteuttavat (Jegatheesan 2013), useimmiten koirien kanssa (Correale ym. 2017; Cunha ym. 2019). Kutsunkin eläinavusteista pedagogiikkaa tässä tutkimuksessa 'koira-avusteiseksi pedagogiikaksi' ja koulussa työskenteleviä koiria 'koulukoiriksi'.

Aiempi empiirinen tutkimus on keskittynyt siihen, miten koira-avusteinen työ vaikuttaa sen kohteena oleviin ihmisiin, esimerkiksi oppilaisiin (Barker ym. 2016; Colarelli ym. 2017) tai mitä vaikutuksia työskentelyllä on koiralle (Glenk 2017; Hautamäki, Ramadan, Ranta, Haapala, \& Suomela-Markkanen 2018). Työntekijän näkökulma on jäänyt vähälle huomiolle, ja siksi rajaan tutkimuksen opettajien kokemuksiin.

Voidaksemme yhä paremmin ymmärtää työn tuunaamista koskevien muutosprosessien merkitystä työntekijälle, työyhteisölle ja muille sidosryhmille keskityn yhteen erityiseen työn tuunaamisen tapaan, koira-avusteisen pedagogiikan avulla tehtävään opetustyöhön. Tarkastelen opettajien työn tuunaamista sekä sitä, miten opettajat kuvaavat ja merkityksellistävät työssään tapahtuneita muutoksia työn tuunaamisen näkökulmasta ja miten koira-avusteinen työ linkittyy heidän hyvinvointiinsa. Teoreettinen viitekehys muodostuu työn vaatimukset ja voimavarat (TV-V) -mallin (Bakker ym. 2014; Demerouti ym. 2001) ja työn tuunaamisen (Tims \& Bakker 2010; van Wingerden, Derks \& Bakker 2017) yhdistelmästä. Tutkimus tarjoaa uutta tietoa aikuiskasvatuksen kenttään työn tuunaamisesta, toiminnasta, jonka avulla työntekijät voivat kehittyä ja oppia uutta työn kontekstissa. Samalla tuotan tuoretta tietoa eläinavusteisesta työstä valottamalla aihepiiriä työntekijän kokemusten kautta.

\section{TYÖN VAATIMUSTEN JA VOIMAVAROJEN TUUNAAMISTA}

'Työn tuunaamisella' tarkoitetaan työntekijän omaehtoista toimintaa, jolla tämä muokkaa työtään omien motiiviensa, vahvuuksiensa ja kiinnostuksensa kohteiden suuntaisesti. Työtehtävien ja niiden tekemisen tavan muuttaminen on keskeinen työn tuunaamisen muoto (Lazazzara ym. 2019). Työn tuunaaminen on yhdistetty TV-V-malliin, jonka mukaan jokaisessa työssä on sille tyypillisiä piirteitä: työn vaatimukset vaativat työntekijältä fyysistä tai psyykkistä panostusta ja kuluttavat hänen energiaansa, työn voimavarat taas edesauttavat työtavoitteiden saavuttamista ja henkilökohtaista kehittymistä.

TV-V-mallissa on kaksi hyvinvointiin liittyvää prosessia: 1) energian ehtymisen polku ja 2) motivaatiopolku. Energian ehtymisen polulla liialliset työn vaatimukset kuormittavat työntekijää, voivat johtaa heikentyneeseen hyvinvointiin ja sen myötä muun muassa työssä suoriutumisen heikkenemiseen. Motivaatiopolulla työn voimavarat edistävät työntekijöiden motivaatiota ja hyvinvointia ja siten edesauttavat esimerkiksi työhön tai organisaatioon sitoutumista (kts. esim. Bakker ym. 2014; Demerouti ym. 2001).

Työtään tuunaamalla työntekijä voi vähentää työn kuormittavia vaatimuksia, lisätä työn voimavaroja ja siten vaikuttaa omaan työhyvinvointiinsa (Peral 2016; van den Heuvel ym. 2015). Näin työntekijä pyrkii edistämään työnsä ominaisuuksien sekä omien tarpeidensa, kykyjensä ja toiveidensa yhteensopivuutta (Tims \& Bakker 2010). Työn tuunaamisen on muun muassa osoitettu lisäävän työn imua (Bakker ym. 2012; Harju ym. 2016) ja työtehtävistä suoriutumista (Tims ym. 2015). Toistaiseksi tiedetään vain vähän siitä, voisiko menetelmällä olla myös kielteisiä seurauksia. Kysymys kiinnostaa tutkijoita, ja muun muassa työpsykologian tutkijat Arnold B. Bakker ja Wido G. M. Oerlemans (2019) raportoivat, 
KOIRA-AVUSTEISET

INTERVENTIOT LISÄÄVÄT

OPPILAIDEN MYÖNTEISIÄ

ASENTEITA KOULUA JA

OPPIMISTA KOHTAAN.

että päivittäinen työn tuunaaminen vaikuttaa sekä myönteisesti että kielteisesti työn imuun.

Opetustyölle tyypillisiä työn vaatimuksia ovat esimerkiksi fyysinen työympäristö, oppilaiden ongelmallinen käyttäytyminen ja emotionaalisesti haastavat tilanteet (Hakanen ym. 2006; van Wingerden ym. 2017). Työn voimavaroina on mainittu muun muassa esimiehen ja kollegojen tuki, työroolin selkeys, innovatiivinen työympäristö sekä rakentava palaute oppilailta ja heidän vanhemmiltaan (Hakanen ym. 2006; van Wingerden ym. 2017). Tässä tutkimuksessa tarkastelen työn tuunauksen tapana uuden pedagogisen menetelmän, erityisesti koira-avusteisen pedagogiikan, hyödyntämistä opetustyössä.

\section{Koira-avusteinen pedagogiikka}

Eläinavusteiset menetelmät pohjautuvat ajatukseen ihmisen ja eläimen välisestä siteestä ja lajien välisestä vuorovaikutuksesta. Niiden on osoitettu edistävän etenkin ihmisen hyvinvointia, mutta siitäkin on viitteitä, että vaikutukset voivat olla myönteisiä eläimelle (Glenk 2017; Hautamäki ym. 2018; Wells 2007). Tosin kielteisistäkin vaikutuksista on raportoitu (King ym. 2011), ja eläimen hyvinvoinnista huolehtiminen onkin erittäin tärkeää koira-avusteisessa työssä (Fine \& Andersen 2021).

Eläinavusteinen työ on yleistynyt opetuksessa ja kasvatuksessa, ja eläinavusteista pedagogiikkaa toteutetaan useimmiten koirien kanssa (Correale ym. 2017; Cunha ym. 2019). Koira-avusteisuus on osoittautunut hyödylliseksi työn kohteena oleville ihmisille (Barker ym. 2016; Colarelli ym. 2017). Koiraavusteisen pedagogiikan on havaittu vaikuttavan myönteisesti oppilaiden lukutaitoon (le Roux ym. 2014), empatiaan (Anderson \& Olson 2006; Hergovich ym. 2002; Tissen, Hergovich \& Spiel 2007) ja sosiaaliseen vuorovaikutukseen vetäytyvien oppilaiden parissa (Kotrschal \& Ortbauer 2003).

Aiemmat löydökset koira-avusteisten interventioiden myönteisistä vaikutuksista oppilaiden empatian ja sosiaalisten taitojen kehittymiseen saattavat vähentää opettajan työhön liitettyjä vaatimuksia, muun muassa oppilaiden haastavaa käytöstä ja emotionaalisesti haastavia työtilanteita tarkasteltaessa (Hakanen ym. 2006; van Wingerden ym. 2017).

Koira-avusteisten interventioiden on osoitettu lisäävän oppilaiden myönteisiä asenteita koulua ja oppimista kohtaan (Beetz 2013), mikä puolestaan voi johtaa lisääntyneeseen myönteiseen palautteeseen oppilailta tai heidän vanhemmiltaan tai molemmilta. Koiran läsnäolon on myös havaittu parantavan työyhteisöjen sosiaalista kommunikaatiota (Hall ym. 2017) ja edistävän ryhmän jäsenten välistä yhteistyötä ja ystävällistä käytöstä (Colarelli ym. 2017). Koiran tuominen työpaikalle voi lisätä opettajan työn voimavaroja edistämällä työyhteisön toimintaa.

Työn vaatimuksia ja voimavaroja koskevien vaikutusten lisäksi suorat opettajan hyvinvointia koskevat myönteiset vaikutukset ovat mahdollisia. Aiemmat tutkimukset osoittavat ihmisen ja koiran välisen vuorovaikutuksen myönteiset terveysvaikutukset: esimerkiksi koiran kanssa vietetty aika lisää mielihyvähormoni oksitosiinin eritystä, ja stressihormoni kortisolin eritys puolestaan vähenee (katso esim. Brelsford ym. 2017). Lisäksi pelkästään mahdollisuus ottaa oma koira mukaan töihin vähentää työntekijän ahdistusta ja stressiä (Hall ym. 2017).

Muunkinlaiset seuraukset ovat kuitenkin mahdollisia. Koiran tuominen työpaikalle voi aiheuttaa vastustusta, ja koira koetaan kielteisenä esimerkiksi allergioiden, hygienian tai koiria koskevien kokemusten, muun muassa pelkojen, takia (Hall ym. 2017). Näin työn tuunaaminen koira-avusteisella pedagogiikalla voi johtaa työn vaatimusten lisääntymiseen tai voimavarojen heikkenemiseen ja siten vaikuttaa työntekijän hyvinvointiin. Tarvitaankin lisää tutkimusta koirista työpaikoilla täsmentämään kuvaa. 
Tämän tutkimuksen tarkoitus on tuottaa uutta tietoa työn tuunaamisesta sekä opettajien siihen liittämistä myönteisistä ja kielteisistä kokemuksista. Tarkastelen koira-avusteista toimintaa osana opettajan työtä ja pyrin ymmärtämään, miten opettajat kokevat työn tuunaamisen muuttavan työn vaatimuksia ja voimavaroja sekä miten he liittävät muutokset omaan hyvinvointiinsa.

\section{MENETELMÄT}

Tutkimuksen empiirisenä aineistona on 14 puolistrukturoitua haastattelua, jotka toteutettiin koiraavusteista pedagogiikkaa työssään hyödyntävien tai hiljattain hyödyntäneiden suomalaisten ala- ja yläkoulun luokan- ja aineenopettajien sekä erityisopettajien parissa. Etsin haastateltavia omien kontaktieni ja aiheeseen liittyvien sosiaalisten mediakanavien kautta sekä lumipallo-otannalla, jolloin pyysin haastateltavalta vinkkejä muista koira-avusteista työtä tekevistä opettajista.

Toteutin haastattelut lokakuusta 2017 syyskuuhun 2018. Kaikki haastatellut olivat naisia, ja useimmat olivat käyneet tai olivat menossa koira-avusteista työtä koskevaan täydennyskoulutukseen. Useimmat työskentelivät työhön soveltuvuustestatun koiran kanssa (ks. esim. Koirat kasvatus- ja kuntoutustyössä ry 2020).

Nauhoitin haastattelut ja litteroin ne tekstimuotoon. Analysoin aineiston teoriaohjaavan sisällönanalyysin (Tuomi \& Sarajärvi 2018; katso myös Leppisaari 2020) periaatteita noudattaen. Analyysin apuna käytin tietoa työn tuunaamisesta. Sen sijaan että olisin testannut teoriaa uudessa kontekstissa, pyrin laadullisen aineiston analyysilla avaamaan uusia näkökulmia ja ajatuspolkuja aihepiiristä. Palasin vertaamaan aineistosta nousevia havaintoja olemassa olevaan tietoon ja kehitin löydöksiä teoreettisen ymmärryksen pohjalta (Tuomi \& Sarajärvi 2018).

Käytin analyysin apuna NVivo 11 -ohjelmistoa. Alustavassa analyysissa kävin koko aineiston läpi etsien ilmauksia siitä, oliko koira-avusteisen pedagogiikan omaksuminen uudeksi työtavaksi ollut omaehtoista ja aktiivista toimintaa, eli voiko sitä kutsua työn tuunaamiseksi. Koska jokainen haastattelu täytti tämän kynnyskriteerin, varsinaisen sisällönanalyysin ensivaiheessa ryhdyin selvittämään sitä, miten haastateltavat kertoivat muutoksista työssään. Erittelin ne työn vaatimuksia ja voimavaroja käsitteleviksi kategorioiksi. Seuraavaksi etsin haastateltujen kuvauksia siitä, miten opettajat kertoivat koira-avusteisen työmuodon vaikuttaneen heidän hyvinvointiinsa.

Tutkimusaineisto ei kuvaa objektiivisesti todellisuutta, vaan se ymmärretään haastateltavien subjektiivisina kokemuksina, jotka ovat muodostuneet haastattelutilanteessa kertomuksiksi. Kertomusten kautta haastateltavat merkityksellistivät ja tekivät ymmärrettäväksi kokemiaan tapahtumia ja tilanteita omista näkökulmistaan. Tehtävänäni oli analysoida kerrottuja kokemuksia teoreettisen viitekehyksen valossa ja tuottaa lukijalle strukturoitu kokonaiskuva siitä, miten haastateltavien kokemukset lisäävät ja syventävät ymmärrystä tutkittavasta asiasta (Eriksson \& Kovalainen 2008; Tuomi \& Sarajärvi 2018).

Tulosten raportoinnissa käytän osallistujista juoksevaa numerointia (H1 - H14) ja kutsun heidän koiriaan anonymiteetin säilyttämiseksi keksimilläni nimillä. Kunkin haastattelulainauksen jälkeen identifioin haastateltavan opettajan haastattelun järjestysluvulla, kerron työtehtävien luonteen ja sen, kuinka pitkä kokemus hänellä on koira-avusteisesta työstä.

\section{LÖYDÖKSET: KOIRAN KANSSA TÖISSÄ, MIKÄ MUUTTUI?}

Koira-avusteisella pedagogiikalla työtään tuunanneet opettajat kuvasivat muutoksia työssään monipuolisesti. Koiran kanssa toteutettavat oppitunnit olivat antaneet heille mahdollisuuden miettiä irtautumista olemassa olevasta materiaalista, kuten oppikirjoista, tai paikasta, kuten luokkahuoneesta. Opetusta toteutettiin myös uudenlaisilla välineillä ja aiempaa enemmän ulkona. Useilla opettaja-koira-työpareilla oli käytössään apuvälineitä, kuten kangasnoppia, pyöritettäviä hyrriä tai kangaspusseja, joihin sai sijoitettua tehtäviä.

Koiran avulla voitiin käsitellä uudella tavalla sisällöllisiä asioita, vaikkapa havainnollistaa silmien värien periytymistä tai mittayksiköiden eroja. Esimerkiksi matematiikan tunnilla mittayksiköitä ja mittaamista 


\section{KOIRAN KANSSA}

\section{TYÖSKENTELY VÄHENSI}

\section{FYYSISEN TYÖYMP ÄRISTÖN \\ KUORMITUSTEKIJÖIT $\ddot{A}$,}

\section{KUTEN MELUA.}

harjoiteltiin kirjatehtävien sijasta mittaamalla koulukoiran kehon osia tai koulukoira pyöräytti kangasnoppaa, jonka taskusta paljastui seuraava äidinkielen tehtävä.

Haastatellut kuvasivat koiran kanssa työskentelyn yhtäältä vähentäneen joitain työn vaatimuksia mutta kokivat toisaalta työn vaatimusten lisääntyneen. Opettajat kuitenkin puhuivat vaatimusten lisääntymisestäkin tyypillisesti myönteiseen sävyyn, mikä voisi viitata heidän haluunsa tuoda esiin se, että vaikka opettajat kokivat koiran kanssa työskentelyn mielekkääksi, koira-avusteinen pedagogiikka ei ollut "puuhastelua" vaan vaati ponnisteluja ja vaivannäköä. Haastatteluissa olivat vahvasti esillä työn tuunaamisen tuottamat myönteiset muutokset työssä, joita tulkitsen työn voimavarojen lisääntymisenä. Tarkastelin työn vaatimusten ja voimavarojen mallia mukaillen myös sitä, miten opettajat puhuivat hyvinvoinnistaan ja siitä, miten he itse liittivät työn tuunaamisen koiraavusteisen pedagogiikan avulla hyvinvointiinsa.

\section{Koira-avusteinen työ ja työn vaatimukset}

Haastatteluissa nousi olennaisena esiin oppilaiden haastavan käytöksen, kuten aggressiivisuuden, ja oppilaiden keskinäisten ristiriitojen väheneminen. Koiran läsnäolo oli muutoksessa keskeistä, sillä oppilaat halusivat koiran viihtyvän luokassa, eivätkä halunneet aiheuttaa koiralle pelkoa tai jännitystä riidoilla.

"On vähemmän riitoja ja asiat sujuu paremmin koiran avulla. Tottakai se tuo mulle sellaista hyvää oloa, et mä haluun olla hyvä opettaja."

H10, erityisluokanopettaja, koira-avusteista työtä useita vuosia
Opettajat kokivat lisäksi, että työn tuunaaminen koira-avusteisella pedagogiikalla oli vähentänyt emotionaalisesti kuormittavia työtilanteita ja helpottanut vuorovaikutusta koskevien haasteiden kanssa toimimista. Oppilaisiin oli monesti helpompi ottaa kontaktia koiran kautta, esimerkiksi siten, että oppilas sai silitellä koiraa samalla kun jutteli opettajan kanssa. Vahvimmin nämä asiat nousivat esiin erityisopetuksessa, jossa oppilailla saattoi olla vuorovaikutukseen liittyviä tekijöitä, kuten kehitysvamma tai autismin kirjon piirteitä.

"[m] un oppilaat on lähtökohtaisesti tosi varautuneita vieraita aikuisia kohtaan ja niitten ei oo helppo jutella aikuisen kanssa niin tää koira on ollu mulle erinomainen väline siihen, että mä oon saanut luotua sen keskusteluyhteyden ja synnytettyä sen luottamuksen joka on tullu huumorin ja ilon kautta."

$\mathrm{H} 4$, erityisluokanopettaja, koira-avusteista työtä epäsäännöllisesti useita vuosia, säännöllistä noin vuosi

Opettajat kertoivat laajasti koira-avusteisen pedagogiikan myönteisistä vaikutuksista oppilaisiin ja opetusryhmän ilmapiiriin. Esiin nousivat muun muassa rauhallisuuden, rentouden ja muiden huomioimisen lisääntyminen. Koiran kanssa työskentely oli vähentänyt fyysisen työympäristön kuormitustekijöitä, kuten melua, koska oppilaat pyrkivät omassa käyttäytymisessään huomioimaan koiran läsnäolon.

Kaikki haastateltavat kokivat, että koira-avusteisen pedagogiikan tuominen osaksi omaa työtä lisäsi jollakin tavalla työn vaatimuksia. Vaatimuksien lisääntyminen oli väliaikaista, esimerkiksi uuden työmenetelmän käyttöönottovaihe, tai pysyvää. Siihen liittyi sekä kuormittavia että myönteisiä kokemuksia.

Opettajat kertoivat, että työn tuunaaminen lisäsi työn vaatimuksia väliaikaisesti muun muassa siksi, että uuden pedagogisen menetelmän tuominen osaksi omaa työnkuvaa vaati paljon pohjatyötä. Koiran tuominen koulu- ja työympäristöön herätti sidosryhmissä monenlaisia ajatuksia ja tunteita, joita ei ehkä johonkin muunlaiseen uuteen pedagogiseen lähestymistapaan olisi liittynyt. Opettajat neuvottelivat uuden 
työmenetelmän käyttöönotosta rehtorin tai muiden päättävien tahojen kanssa. He olivat yhteydessä muihinkin sidosryhmiin, kuten kollegoihin, terveydenhoitajaan tai oppilaiden vanhempiin, ja keskustelivat sidosryhmäläisten kanssa mahdollisuudesta aloittaa koira-avusteinen työskentely omassa koulussaan. Jotkut opettajat kohtasivat lisääntyneitä vaatimuksia työpaikan sosiaalisissa suhteissa, kun kollega tai muu koulun henkilökunta vastusti koira-avusteisen pedagogiikan käyttöönottoa tai suhtautui siihen epäilevästi, vähätellen tai kateellisesti.

”Ei tää pelkkää onnea ja autuutta ollut, että silloin kun me tätä ruvettiin tänne taloon tuomaan, niin tää herätti ihan selvästi kateutta ja kyllä me jouduttiin tosi paljon perustelemaan tätä. Sitten kun meidän esimiehet ja johto oli tästä niin innoissaan niin sitten sekin just herätti vähän kysymyksiä että miks tälle annetaan näin paljo tilaa ja mahdollisuuksia ja niin kuin varmasti jotkut kokee että se oli jostain muusta pois siinä kohtaa mä luulen että nyt tilanne on rauhoittunut."

H4, erityisluokanopettaja, koira-avusteista työtä epäsäännöllisesti useita vuosia, säännöllistä noin vuosi

Opettajat kuvasivat työn vaatimusten lisääntyneen sitä kautta, että he käyttivät omia resurssejaan, esimerkiksi aikaa ja rahaa, voidakseen toteuttaa koiraavusteista pedagogiikkaa ammattimaisesti. He esimerkiksi vahvistivat omaa tietopohjaansa eläinavusteisesta toiminnasta ja kouluttivat koiransa.

"Koulutuksen maksoin itse, yöpymiset, kuljetukset ja kaikki nää tämmöset ja tietysti viikonloput. Aika paljon oli sitten viikonloppuisin luentoja, niin tottakai ne meni sitten omaan piikkiin. Mutta koulutus oli tosi antoisa."

H11, erityisluokanopettaja, koira-avusteista työtä noin vuosi

Koira-avusteisen pedagogiikan aloittamisessa opettajat olivat yleensä vahvasti suunnittelemassa käytännön järjestelyjä, muun muassa tiloja ja aikatauluja. Tiloja koskevat käytännöt vaihtelivat kouluittain: joissakin koulukoira oli tervetullut kaikkiin tiloihin, toisissa koulukoiratyöskentely järjestettiin kokonaan omassa erillisessä rakennuksessaan. Valmisteluvaiheen lisääntyneet vaatimukset koettiin väliaikaisiksi ja vaivan arvoisiksi.

Koira-avusteisen pedagogiikan hyödyntäminen lisäsi opettajan työn vaatimuksia pysyvämminkin, koska se synnytti tarpeen suunnitella ja uudistaa oppituntien tai opetuksen toteuttamistapaa ja -rakennetta. Opettajat kuitenkin kuvasivat työtehtävien uudelleenorganisoinnin vaatimuksia myönteisesti ja kertoivat nauttivansa mahdollisuudesta käyttää luovuuttaan ja ongelmanratkaisukykyään uusilla tavoilla, vaikka se vaati aikaa ja vaivaa.

”Että silloin kun koiraa käyttää työvälineenä niin joutuu enempi suunnittelemaan sitä työtään, sitä päivää ensinnäkin, kun koira tulee. Ja sitten niitä vaikutuksia [mitä koira-avusteisella toiminnalla on], esimerkiksi pidän kirjaa [--] nykyisin en enää kirjaa joka päivä, mutta nyt semmoista plussaa vai miinusta esimerkiksi mitä näen koirapäivistä. Niin enempi on tullut tämmöstä että miettii niitä pedagogisia ratkaisuja ja toimintoja silloin kun koira on siellä mukana.”

H6, erityisluokanopettaja, koira-avusteista työtä useita vuosia

"Mun mielestä on tosi kiva suunnitella, mä joudun oikeesti vähän miettii miten mä ne jutut teen. Mä en voi toteuttaa mä voi tukeutua siihen oppikirjaan ihan suoraan."

H2, koira-avusteista työtä useita vuosia

Koulukoiran kanssa työskentely lisäsi työhön käytettyä aikaa, sitä kului esimerkiksi koiran kouluttamiseen tehtäviinsä. Jotkut opettajat kokivat, että heidän tuli erityisen hyvin huolehtia koiran siisteydestä ja puhtaudesta koiran työpäivinä. Kurakeleillä koiralle puettiin kurapuku, vaikka sellaista ei sillä muuten käytetty. Koulukoirapäivinä jotkut opettajat käyttivät työmatkaansa eri kulkuneuvoja tai -reittejä kuin muina työpäivinä. Toisille opettajille koirapäivät toivat aikataulumuutoksia, kun täytyi esimerkiksi herätä tavallista aiemmin ehtiäkseen ulkoiluttaa koiraa tavanomaista 


\section{TyÖTAPA SAI OPETTAJAT \\ INNOSTUMAAN TYÖST ̈̈}

\section{AIVAN UUDELLA TAVALLA, MIK ̈̈ LISÄSI ENERGISYYTT $\ddot{A}$.}

pidempään, jotta sen vireystila olisi sopiva työpäivään. Yleensä lisääntyneet vaatimukset kuitenkin käännettiin myönteisiksi.

"Vaikka onhan siinä tietysti se, että jos me mennään yhdeksäksi niin mulla soi kello 6.00 ja mä lähden ennen 7.00 sen kans lenkille, että sillai tietysti itsellekin erilainen aamu. Mutta toisaalta sitä taas ajattelee että ei mun tulisi muuten lähdettyä aamulenkille."

H3, erityisluokanopettaja, koira-avusteista työtä noin vuosi

Koiran kanssa työskentely vaikutti työpäivän rytmittämiseen ja tauottamiseen. Esimerkiksi luokan aamurutiineihin oli tuotu mukaan koiran kanssa tehtäviä aktiviteetteja, joiden koettiin tarjoavan mahdollisuus rentoon ja positiiviseen päivän aloitukseen, vaikka aika saattoikin olla pois varsinaisen sisällön opetuksesta. Opettajat kantoivat huolta koiriensa hyvinvoinnista ja jaksamisesta työpäivän aikana ja toivat esiin välituntien ja tauotuksesta huolehtimisen tärkeyden. Oppitunneilla koiralle oli järjestettävä mahdollisuus vetäytyä lepäämään sille rauhoitettuun paikkaan. Koirat työskentelivät opettajan kanssa tyypillisesti muutamana päivänä viikossa, ja "koirapäivät" loivat työviikkoon uudenlaista rytmitystä.

\section{Koira-avusteinen työ ja työn voimavarat}

Koiran kanssa työskentelevät opettajat kokivat, että työn tuunaaminen vahvisti ja lisäsi heidän työnsä voimavaroja monella tavoin: heidän ammatillinen arvostuksensa kohosi ja he saivat aiempaa enemmän myönteistä palautetta työstään niin esimieheltään kuin kollegoiltaan ja sidosryhmiltä. "[s]it toinen on se että jos mä en ajattele oppilaita [ja heille tulevia hyötyjä], niin se että mä oon kokenu että mä oon saanu mun työnantajalta tosi paljon sitä palautetta."

H4, erityisluokanopettaja, koira-avusteista työtä epäsäännöllisesti useita vuosia, säännöllistä noin vuosi

"Sen huomaa [että koira-avusteinen pedagogiikka on ollut oikea valinta] tietysti myös positiivisesta palautteesta mitä tulee perheistä vanhemmilta ja huoltajilta"

H9, erityisluokanopettaja, koira-avusteista työtä noin vuosi'

Haastatellut kertoivat uuden pedagogisen menetelmän laajentaneen heidän työrooliaan. Koira-avusteinen pedagogiikka on suhteellisen uusi työmuoto, ja sen hyödyntäminen oli tuottanut opettajille erityistä asiantuntijuutta. Monia kutsuttiin erilaisiin tilaisuuksiin esitelmöimään aiheesta, haastateltiin medioihin tai pyydettiin kouluttajiksi uusille kohderyhmille, lähinnä muille opettajille. Työrooli laajeni uusiin oppilasryhmiin ja opetusaiheisiin: koira-avusteista toimintaa haluttiin useissa kouluissa hyödyntää laajemminkin kuin vain kyseisen opettajan aiemman työnkuvan kattavalle oppilasjoukolle.

”Ja sitte tuli semmosta viestiä paljon että just sitä että voisko tätä antaa muillekin kuin pelkästään [--] Tai voisiko muutkin hyötyä tästä kun vaan meidän ryhmän oppilaat, ja sitten ruvettiin miettimään niitä keinoja että miten se saatais jaettua muillekin.”

$\mathrm{H} 4$, erityisluokanopettaja, koira-avusteista työtä epäsäännöllisesti useita vuosia, säännöllistä noin vuosi

Koulukoiran kanssa työskentely oli laajentanut yhteistyötä omassa organisaatiossa, ja koiran kanssa tehtiin työtä aiempaa useamman kollegan kanssa. Työn tuunaaminen lisäsi ammatillista verkostoitumista laajemminkin, esimerkiksi muiden koira-avusteista pedagogiikkaa hyödyntävien opettajien tai koira-avusteisesti työtään tekevien muiden ammattiryhmien edustajien kanssa. 
”Sit mä otin eri oppilaita ja rupesin tekeen myös kuraattorin kans [--] Ja enhän mä muuten koulukuraattorin kanssa oo tekemisissä, mut eri opettajien [--] ku sellasia että juttelee jostain tietystä oppilaista että hyötyisikö ne tästä tai pystyisinks mä koiran kautta jeesata tässä kohtaa. Tai tai sit mä oon käynyt vetämässä niille jonkun oppitunnin jossain muussa luokassa, vaikka mun omien oppilaiden kanssa niin sillä tavallahan se on kyllä joo ja mun kutosethan veti ihan oppitunteja myös ykkösille koiran kanssa."

H2, koira-avusteista työtä useita vuosia

Vaikka jotkut opettajat olivat kokeneet kielteisiä muutoksia työpaikan sosiaalisissa suhteissa kollegoiden tai koulun muiden työntekijöiden asennoiduttua kielteisesti uuteen toimintamuotoon, työyhteisön sosiaaliset suhteet olivat sen myötä pääosin parantuneet.

”Koiran tuominen sinne työpaikalle, se ei tosiaan niinku ole pelkästään vaan oppilaita varten, että se ei auta pelkästään oppilaita eikä se auta pelkästään mua, vaan se on myös monille mun työkavereille. He itse tulee hakeutumaan, ihan samalla tavalla, kun minä itse välillä, istumaan sinne opettajanhuoneen lattialle koiran kanssa niin, ne saattaa tulla niinku tunnilta sillee niiku 'Aah, jes, Nalle on täällä'."

H 13, kieltenopettaja, koira-avusteista työtä useita vuosia

Usein muut työyhteisön jäsenet halusivat viettää aikaa koulukoiran parissa.

\section{Työn tuunaaminen ja hyvinvointi työssä}

Haastatellut kokivat, että työn tuunaaminen koiraavusteisen pedagogiikan avulla ja koiran kanssa työparina toimiminen olivat yhteydessä heidän hyvinvointiinsa. Työtapa sai heidät innostumaan työstä aivan uudella tavalla, mikä lisäsi energisyyttä. Useimmat kertoivat kokeneensa työssään aiempaa vähemmän väsymystä ja stressiä, ja kaksi oli saanut työn tuunaamisesta apua työuupumuksesta toipumiseen.
"Tottakai tää on motivoinut mua työntekijänä että mun ajatuksiin, suunnitelmiin ja ajatuksiin on uskottu ja luotettu ja kannustettu että 'tee vaan näin ja näin', niin onhan se niinku motivoinut. Se että mä oon saanu keksiä uutta ja olla luomassa jotain semmoista, mitä tuolla ei oo koskaan ennen tehty."

H4, erityisluokanopettaja, koira-avusteista työtä epäsäännöllisesti useita vuosia, säännöllistä noin vuosi

"Sitten ehkä semmoinen tympääntyminen omaan työhön oli käynnissä, niin mä olen tämän koiran avulla jotenkin löytänyt siitä sellaisia asioita, että mä oon niinku innostunut uudestaan ja mä mä en haluais siitä luopua. Jotenkin se opettajuus on löytynyt uudella tavalla”

H12, luokanopettaja, kielten aineenopettaja, koira-avusteista työtä noin vuosi

Moni opettaja kuitenkin kertoi, että koulukoirapäivät vaativat paljon energiaa, koska oppilaiden lisäksi piti huomioida koira. Koulukoirapäivän jälkeen opettajat saattoivat olla väsyneempiä kuin muulloin, mutta koira-avusteisen työn myönteiset puolet saivat heidät voimaan työssään paremmin.

”Oon tykänny aivan valtavasti enkä missään tapauksessa haluaisi luopua siitä hommasta, sillä mä oon saanut sen työn just niin oman näköiseksi kun on halunnut. Mutta se on tosi paljon raskaampaa, vaati tosi paljon enemmän suunnittelua valmistelua ja etukäteen mutta myös sitten sillä tunnilla ja sinä päivänä Se vaati aivan erilaisen työpanos itseltä että jos on Penni on illalla väsyksissä niin kyllä mäkin oon. Niinä päivinä aina huomattavasti väsyneempi kuin tavallisen koulupäivänä kun pitää kuitenkin saada sitten se kaikkien yhteistyö toimivaksi ja pidettävä huoli että koira toimii ja kun sitä ei voi aina tietää miten se toimii. Pitää olla suunnitelma ja varasuunnitelmia monta."

H5, laaja-alainen erityisopettaja, koira-avusteista työtä noin vuosi 
OpetTajat KUVASIVAT

TYÖN VAATIMUSTEN

\section{LISÄÄNTYMISEN LÄHES AINA \\ MYÖNTEISESS $\ddot{A}$ VALOSSA}

\section{TAI PITIVÄT PANOSTUKSIA}

\section{VAIVAN ARVOISINA.}

Opettajat kokivat työn tuunaamisen lisänneen myönteisiä kokemuksia työstä. Koira-avusteinen työ oli lisännyt heidän työtyytyväisyyttään sekä työhön ja organisaatioon sitoutumistaan. Haastatellut liittivät myönteiset muutokset työhyvinvoinnissa työn voimavarojen lisääntymiseen tai kiinnostavissa haasteissa onnistumiseen. Samoin kokemus siitä, että oma koira oli iloksi ja hyödyksi muille, tuotti haastateltaville myönteisiä tuntemuksia:

"Kun me tullaan Rekun kanssa töistä kotiin, niin kyllä mulla on niin hieno fiilis aina kun mä saan kehua sitä kuinka hienosti se oli päivän. Kyllä mieskin väliin nauraa että sä oot taas ihan intoa piukassa kun mä sitten sillekin kerroin että tänään kuule sitten taas tänään se teki sitä ja sitä, ja oli semmosta ja semmosta. Siitä tulee itselle hirvittävän hyvä filis ja kun aina kuitenkin menee hyvin ja onnistuu, ja onhan se tietysti työpäivän aikana kiva katsella sitä kun ne [oppilaat] tulee sitä halaileen pihalla ja toinen nauttii vaan, ja on että 'rapsuta vähän vielä lisää ja silitä vaan’. Se on väkisinkin niin, että sen koko päivän vaan hymyilee."

H3, erityisluokanopettaja, koira-avusteista työtä noin vuosi

"Se [työantajalta saatu positiivinen palaute] on ruokkinut sitten taas mun omaa itsetuntoa ja itseluottamusta, ja motivoinut tietysti tekemään enemmän töitä että sehän on tietysti työnantajan intresseissä myöskin."

H4, erityisluokanopettaja, koira-avusteista työtä epäsäännöllisesti useita vuosia, säännöllistä noin vuosi
”Tottakai tää koira lisää sitä vielä vahvistaa sitä että on tyytyväinen omaan työhön ja siihen miten toimii. [--] Se [saatu positiivinen palaute] lisää sitä tyytyväisyyttä ja uskoa siihen että vielä muutama vuosi jaksetaan"

H9, erityisluokanopettaja, koira-avusteista työtä noin vuosi

Joissain tapauksissa vastoin opettajan tahtoa keskeytynyt koira-avusteinen opetus tai epävarmuus sen jatkumisesta koettiin erittäin negatiiviseksi. Muutamat opettajat jopa harkitsivat vakavasti toisen työpaikan hakemista tai mahdollista uudelleenkouluttautumista tehtäviin, joissa koira-avusteisella työskentelyllä olisi vakiintuneempi asema kuin opetusalalla. He yleensä liittivät työn tuunaamisen kielteiset vaikutukset työyhteisön sosiaalisiin suhteisiin. Jos kollega tai joku muu työyhteisössä suhtautui kielteisesti koiraavusteiseen opetukseen ja asetti sen toteuttamisen vaakalaudalle, tai menetelmän toteuttaminen keskeytettiin, tilanne koettiin epäoikeudenmukaiseksi eikä perusteluja, esimerkiksi allergiaa, pidetty oikeutettuna. Vaikka tällaiset tilanteet olivat yksittäisiä, opettajat kokivat ne hyvin negatiivisiksi ja kertoivat niiden vaikuttaneen heidän hyvinvointiinsa.

”Ja vähän semmoisella ajatuksella, että mulla on nyt virka [paikan nimi], mutta jos en mä saa koiraa, jos mä oon vuoden harjoitellut koirani kanssa tätä toimintaa ja siitä tosi innoissani. Niin että jos en mä saa koiraa [paikan nimi] töihin, niin en mä mee sinne itsekään."

H12, luokanopettaja, kielten aineenopettaja, koiraavusteista työtä noin vuosi

”Et mä en nyt oikeen tiedä mitä mä teen tän mun duunin kanssa. Ja sit ois peli kyllä menetetty, jos esimies ois jotenkin että sitä vastaan. Että hänhän on täysin sitä mieltä että hän olisi niin kovasti halunnut suoda minulle tämän mahdollisuuden [hyödyntää koira-avusteista pedagogiikkaa] et kaikki muuttuisi jos tää yksi [allerginen työyhteisön jäsen] vaihtais työpaikkaa."

H14, luokanopettaja, epäsäännöllistä koira-avusteista työtä noin vuosi 
Koiran kanssa työskentely itsessään koettiin mielekkäänä.

"[e]ttä voiko sitä nyt sanoa, että onko ollut parempi opettaja, mutta kyllä se on vaikuttanut silleen, että vois jopa sanoa lapset ovat saaneet viime vuonna laadukkaampaa opetusta tai ainakin ilmapiiriltään parempaa opetusta kuin mitä ehkä muina vuosina."

H7, ohjaava opettaja, koira-avusteista opetusta noin vuosi, ei työskentele haastatteluhetkellä koiraavusteisesti

Koiran silittäminen ja fyysinen läheisyys tuottivat mielihyvää ja auttoivat laskemaan stressiä työpäivän aikana.

\section{POHDINTA}

Tämän tutkimuksen tulosten valossa työtä voi tuunata hyvin monella tavalla. Koira-avusteisen pedagogiikan hyödyntäminen opetustyössä oli tutkimukseen haastateltujen opettajien omaehtoista työmenetelmien kehittämistä omien vahvuusalueiden ja kiinnostuksen kohteiden suuntaisesti, eli se voidaan määritellä työn tuunaamiseksi (Lazazzara ym. 2019; Peral 2016). Tulokseni tukevat aiemmassa tutkimuksessa esitettyä näkemystä siitä, että työtä tuunaamalla voidaan vaikuttaa työssä koettuihin vaatimuksiin ja voimavaroihin (Tims \& Bakker 2010; van den Heuvel ym. 2015). Aiemmasta tutkimuksesta poiketen tutkimukseni osoitti, että sen lisäksi, että työn tuunaaminen vahvisti työn voimavaroja ja vähensi vaatimuksia, se lisäsi työn vaatimuksia tai heikensi voimavaroja. Siten tutkimus tuotti uutta ymmärrystä siitä, miten työn tuunaaminen nimenomaan eläinavusteisesti voi monipuolisesti vaikuttaa työhön ja työntekijän kokemuksiin siitä.

Työn tuunaaminen koira-avusteisen pedagogiikan avulla näytti liittyvän nimenomaan opettajien kokemuksiin niistä vaatimuksista, joita opetustyössä on aiemmin tunnistettu (Hakanen ym. 2006; van Wingerden ym. 2017). Opettajat kokivat, että tuunaaminen muun muassa lievensi oppilaiden ongelmallista käyttäytymistä, vähensi emotionaalisesti haastavia tilanteita ja helpotti jopa fyysistä työympäristöä koskevia vaatimuksia, esimerkiksi vähensi melua. Löydökset ovat yhdenmukaisia aiemman kirjallisuuden kanssa, jossa on havaittu koira-avusteisen opetuksen auttavan sosiaalista vuorovaikutusta ja emotionaalisia taitoja luokassa (Anderson \& Olson 2006; Hergovich ym. 2002; Kotrschal \& Ortbauer 2003; Tissen ym. 2007).

Aiempi tutkimus esittää, että koira-avusteinen pedagogiikka kehittää oppilaiden taitoja, esimerkiksi lukutaitoa (le Roux ym. 2014). Tutkimukseeni haastatellut opettajat eivät suoranaisesti viitanneet oppilaiden tiedollisten taitojen kehittymiseen mutta korostivat sitä, että oppilaiden motivaatio eri tehtäviä ja oppiaineita kohtaan lisääntyi koira-avusteisuuden avulla (vrt. esim. Beetz 2013), minkä puolestaan voi olettaa olevan yhteydessä taitojen kehittymiseen. Löydös viittaa tarpeesta tarkastella eläinavusteiseen työhön sisältyviä mekanismeja. Tutkimus voisi taidollisten valmiuksien kehittymisen lisäksi ottaa aiempaa vahvemmin huomioon tunnetason muutoksia tai eri toimijoiden välisten suhteiden kehittymisen.

Opettajat kokivat myös, että työn tuunaaminen koira-avusteisen pedagogiikan avulla lisäsi työn vaatimuksia, mutta kuvasivat sen lähes aina myönteisessä valossa tai pitivät panostuksia vaivan arvoisina. $\mathrm{Ha}$ vainto tukee työn tuunaamista käsittelevässä kirjallisuudessa käytyä keskustelua siitä, tulisiko työn vaatimukset jaotella haitallisiin (hindrance) ja haastaviin (challenging) vaatimuksiin (Bakker \& Sanz-Vergel 2013; van den Broeck ym. 2010).

Kun omaa työtä tuunataan omien kiinnostuksen kohteiden ja vahvuusalueiden suuntaisesti, ihmiset ovat valmiita myös panostamaan resurssejaan monipuolisesti ja silti kokemaan lisääntyneet vaatimukset mielekkäinä. Työn tuunaaminen oli useimmille haastatelluille opettajille kohtuullisen tuore kokemus, ja useimmat olivat toteuttaneet koira-avusteista pedagogiikkaa noin vuoden verran. Tulevaisuudessa olisi hyvä tutkia työn tuunaamisen vaikutuksia pidemmällä ajanjaksolla, sillä jo tämän tutkimuksen aineistosta oli havaittavissa se, että jotkin lisääntyneet työn vaatimukset olivat väliaikaisia ja vähenivät tai poistuivat nopeasti. On toisaalta on mahdollista, että alkuinnostuksen jälkeen jotkin menetelmään kuuluvista työn 
TUTKIMUKSEN TULEE

KIINNITT $\ddot{A}$ HUOMIOTA

SIIHEN, MITEN TYÖN

TUUNAAMINEN

YKSILÖTASOLLA VAIKUTTAA

SOSIAALISEEN YMP ̈̈RISTÖÖN

JA TYÖYHTEISÖÖN.

vaatimuksista alkavat tuntua kuormittavalta eikä niitä enää nähdä myönteisessä valossa.

Tutkimuksen osallistujat kertoivat työn tuunaamisen koira-avusteisen pedagogiikan avulla vahvistaneen heidän työnsä voimavaroja (Hakanen ym. 2006; van Wingerden ym. 2017). Työroolin laajentuminen ja uusien taitojen kehittyminen koettiin itsessään palkitsevina, mutta ne olivat usein myös yhteydessä kokemukseen ammatillisen arvostuksen vahvistumisesta sekä yhteistyön lisääntymisestä omassa organisaatiossa ja uusissa verkostoissa. Tämän tyyppiset löydökset tuovat uusia näkökulmia yhtäältä työn tuunaamisen tutkimukseen ja toisaalta eläinavusteisen työn vaikutuksia koskeviin tutkimuksiin. Tutkimusta tulisi yhä enemmän kohdistaa työssä tapahtuviin muutoksiin ja vaikutuksiin, joita sillä on työntekijälle itselleen.

Työyhteisön sosiaalisten suhteiden näkökulmasta tutkimuksen löydökset osoittivat tämän kaltaisen työn tuunaamisen voivan johtaa sekä myönteisiin että kielteisiin kokemuksiin - voimavarojen vahvistumiseen ja heikentymiseen. Koiran läsnäolon on osoitettu parantaneen sosiaalista vuorovaikutusta työyhteisössä ja edistävän yhteistyötä ja ystävällistä käytöstä ryhmän jäsenten kesken (Colarelli ym. 2017; Hall ym. 2017). Tässäkin tutkimuksessa suurin osa opettajien kuvaamista vaikutuksista työyhteisön jäsenten välillä oli myönteisiä ja samankaltaisia aiempien tutkimuslöydösten kanssa.

Tutkimus kuitenkin osoitti, että koiran tuomista työyhteisöön ei aina nähdä myönteisenä, ja muut työyhteisön jäsenet saattoivat olla allergisia, pelätä koiria tai epäillä niiden hyötyjä luokassa. Tämä havainto vahvistaa aiemman kirjallisuuden oletuksen siitä, että työyhteisöissä suhtautuminen koiriin voi olla myös negatiivista (Hall ym. 2017). Tulevaisuudessa tutkimuksen tulee kiinnittää aiempaa enemmän huomiota siihen, miten työn tuunaaminen yksilötasolla vaikuttaa sosiaaliseen ympäristöön ja työyhteisöön.

Koiran myönteisistä hyvinvointivaikutuksista ihmisiin on runsaasti tietoa, mutta tutkimusta työhyvinvoinnista koira-avusteisen työn kontekstissa ei ollut löydettävissä. Työn tuunaamista koskeva kirjallisuus on osoittanut (Peral 2016; Tims \& Bakker 2010; van den Heuvel ym. 2015), että työn tuunaaminen vaikuttaa työn vaatimuksiin ja voimavaroihin ja niissä tapahtuneiden muutosten kautta hyvinvointiin. Koiran kanssa työskentelevät opettajat liittävät muutokset työssä erityisesti työhyvinvointiin, kuten työmotivaatioon, työtyytyväisyyteen, työhön sitoutumiseen ja jopa työuupumuksesta toipumiseen.

Muutama haastateltava kertoi heikentyneistä työn voimavaroista - kielteisistä muutoksista sosiaalisissa suhteissa - ja liitti muutokset voimakkaaseen tyytymättömyyteen, sitoutumisen heikkenemiseen, jopa haluun lähteä organisaatiosta. Koira-avusteisen työn tuunaamisen erityispiirre on se, että opettajat kokivat jo koiran läsnäolon parantavan heidän hyvinvointiaan, muun muassa rentouttavan ja vähentävän stressiä. Aiempi tutkimus ihmisen ja koiran vuorovaikutuksesta raportoi lukuisista terveysvaikutuksista ihmiselle (ks. esim. Brelsford ym. 2017; Hall ym. 2017), ja havaintoja on myös molemminpuolisista terveysvaikutuksista (Glenk 2017). Koiran kanssa työskentelevät opettajat tasapainoilevat monien sidosryhmien asenteiden ja toiminnan kanssa, joten useamman sidosryhmän tarkastelu samassa tutkimuksessa olisi arvokasta.

Tutkimusteema oli uusi, eikä aiempaa tutkimusta aiheesta ollut löydettävissä. Tutkimusmenetelmäksi valittu laadullinen lähestymistapa ja 14 haastattelua mahdollistivat ilmiön kuvaamisen monipuolisesti. Tutkimusmenetelmän kautta ilmiötä pyrittiin ymmärtämään syvällisesti ja monelta kannalta. Vastaisuudessa tutkimuksen tulisi hyödyntää pitkittäisaineistoja 
KOIRA-AVUSTEISTA

PEDAGOGIIKKAA KÄYTTÄV̈̈

OPETTAJA KOKEE TYÖNS̈̈

MUUTTUVAN AIEMPAA

MIELEKK $\dddot{A} \ddot{A M M} \ddot{A} K S I$ JA SITEN

MENETELMÄN EDESAUTTAVAN

TYÖHYVINVOINTIA.

tulosten yleistettävyyden vuoksi. Samoin tilastollisen aineiston kerääminen olisi tarpeen. Tulevaisuudessa työn tuunaamisen tutkimus voisi aiempaa enemmän pohtia, millaisia erilaisia työn tuunaamisen tapoja ihmiset työssään toteuttavat ja millaisia vaikutuksia niillä on niin yksilön, työyhteisön kuin työn kohteena olevien ihmisten näkökulmasta. Työn tuunaaminen on linkitetty mahdollisuuteen kehittyä työssä, ja tutkimuksen tulisikin syventää ymmärrystä siitä, miten erilaiset työn tuunaamisen tavat edesauttavat aikuisen oppimista ja kehittymistä.

Tarkastelin tässä tutkimuksessa koira-avusteista toimintaa ainoastaan ihmisen työn näkökulmasta, eikä huomion kohteena ollut se, millaisia vaikutukset ovat koiralle opettajan työparina. Vaikka eläinavusteinen toiminta itsessään ei vaikuta kielteisesti koirien hyvinvointiin (Ng ym. 2014), kielteiset vaikutuksetkin ovat mahdollisia (King ym. 2011). Koulukoira voi työssään kohdata tilanteita, esimerkiksi uusia ympäristöjä tai suuria määriä uusia ihmisiä, jotka voivat altistaa sitä stressille (ks. katsausartikkeli Glenk 2017). Eläinavusteiseen työhön liittyy siten eettisiä kysymyksiä, jotka tulee huomioida koira-avusteisessa pedagogiikassa. Eläinten käyttäytymistutkimuksen ja työelämän tutkimuksen monitieteinen yhdistelmä voisikin tuottaa lisää ymmärrystä sekä työkoiran että työntekijän hyvinvoinnista.

Koira-avusteinen työskentelytapa on sitä hyödyntäville opettajille mielekäs tapa tuunata työtä, ja sitä hyödyntävät opettajat kokevat olevansa sitoutuneita asiaan. Jos työn tuunaaminen epäonnistuu, eli koiraavusteisen pedagogiikan hyödyntäminen ei onnistu, opettajan kokemukset sekä hyvinvoinnista että työhön sitoutumisesta voivat olla hyvinkin negatiivisia. Jos taas työn tuunaaminen onnistuu eli koira-avusteisen pedagogiikan hyödyntäminen on mahdollista, opettaja kokee työnsä muuttuvan aiempaa mielekkäämmäksi ja siten menetelmän edesauttavan hyvinvointia työssä.

Työnsä tuunaamista koira-avusteisen pedagogiikan avulla suunnittelevan työntekijän kannattaakin selvittää etukäteen, miten asiaan omassa työpaikassa suhtaudutaan ja miettiä mahdollisimman neutraalisti tilanteita, joissa koira-avusteinen työ ei onnistukaan. Työnantajan ja esimiesten taas tulee etukäteen huolellisesti pohtia ja keskustella siitä, mikä on organisaation tahtotila sekä selvittää sidosryhmien, kuten oppilaiden, vanhempien, työyhteisön, työterveyden, työsuojelun näkemykset. Ne vaikuttavat siihen, onko tätä pedagogista menetelmää mahdollista menestyksekkäästi toteuttaa.

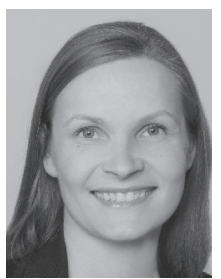

LIISA MÄKELÄ

KTT, FT, professori

henkilöstöjohtamisen yksikkö

johtamisen yksikkö

Vaasan yliopisto

(iD https://orcid.org/0000-0002-

7761-3767 
Anderson, K. L. \& Olson, M. R. (2006). The value of a dog in a classroom of children with severe emotional disorders. Anthrozoos, 19(1), 35-49. https://doi. org/10.2752/089279306785593919

Bakker, A. B., Demerouti, E. \& Sanz-Vergel, A. I. (2014). Burnout and Work Engagement: The JD-R Approach. Annu. Rev. Organ. Psychol. Organ. Behav, 1(April 2016), 389-411. https://doi.org/10.1146/annurevorgpsych-031413-091235

Bakker, A. B. \& Oerlemans, W. G. M. (2019). Daily job crafting and momentary work engagement: A selfdetermination and self-regulation perspective. Journal of Vocational Behavior, 112, 417-430. https://doi. org/10.1016/J.JVB.2018.12.005

Bakker, A. B. \& Sanz-Vergel, A. I. (2013). Weekly work engagement and flourishing: The role of hindrance and challenge job demands. Journal of Vocational Behavior, 83(3), 397-409. https://doi.org/10.1016/j. jvb.2013.06.008

Bakker, A. B., Tims, M. \& Derks, D. (2012). Proactive personality and job performance: The role of job crafting and work engagement. Human Relations, 65(10), 1359-1378. https://doi. org/10.1177/0018726712453471

Barker, S. B., Barker, R. T., Mccain, N. L., Christine, M., Barker, S. B. \& Barker, R. T. (2016). A Randomized Cross-over Exploratory Study of the Effect of Visiting Therapy Dogs on College Student Stress Before Final Exams. Anthrozoös, 29(1), 35-46. https://doi.org/10.1 080/08927936.2015.1069988

Beetz, A. (2013). Socio-emotional correlates of a schooldog-teacher-team in the classroom. Frontiers in Psychology, 4(NOV), 1-7. https://doi.org/10.3389/ fpsyg.2013.00886

Brelsford, V. L., Meints, K., Gee, N. R. \& Pfeffer, K. (2017). Animal-assisted interventions in the classroom - a systematic review. International Journal of Environmental Research and Public Health, 14(7), E669. https://doi.org/10.3390/ijerph14070669

Broeck, A., van den, Cuyper, N. De \& Witte, H. De. (2010). Not all job demands are equal : Differentiating job hindrances and job challenges in the Job Demands - Resources model. European Journal of Work and Organizational Psychology, 19(6), 735-759. https:// doi.org/10.1080/13594320903223839

Colarelli, S. M., Mcdonald, A. M., Christensen, M. S., Colarelli, S. M., Mcdonald, A. M., Christensen, M. S., [--] Honts, C. (2017). A Companion Dog Increases Prosocial Behavior in Work Groups. Anthrozoös, 30(1), 77-89. https://doi.org/10.1080/08927936.2017.127 0595
Correale, C., Crescimbene, L., Borgi, M. \& Cirulli, F. (2017). Development of a Dog-Assisted Activity Program in an Elementary Classroom. Veterinary Sciences, 4(4), 62. https://doi.org/10.3390/ vetsci4040062

Cunha, M. P., Rego, A. \& Munro, I. (2018). Dogs in organizations. Human Relations, 72(4) 778-800. https://doi.org/10.1177/0018726718780210

Demerouti, E., Bakker, A. B., Nachreiner, F. \& Schaufeli, W. B. (2001). The job demands-resources model of burnout. Journal of Applied Psychology, 86(3), 499-512.

Eriksson, P. \& Kovalainen, A. (2008). Qualitative Methods in Business Research. London: Sage.

Fine, A. \& Andersen, S. (2021). A Commentary on the Contemporary Issues Confronting Animal Assisted and Equine Assisted Interactions. Journal of Equine Veterinary Science, 100, 1-7.

Glenk, L. M. (2017). Current Perspectives on Therapy Dog Welfare in Animal-Assisted Interventions. Animals, 7(7), 1-17. https://doi.org/10.3390/ ani7020007

Hakanen, J. J., Bakker, A. B. \& Schaufeli, W. B. (2006). Burnout and work engagement among teachers. Journal of School Psychology, 43, 495-513. https:// doi.org/10.1016/j.jsp.2005.11.001

Hall, S., Wright, H., Mccune, S., Zulch, H., Mills, D., Hall, S., \& Mills, D. (2017). Perceptions of Dogs in the Workplace : The Pros and the Cons. Anthrozoös, 30(2), 291-305. https://doi.org/10.1080/08927936. 2017.1311053

Harju, L. K., Hakanen, J. J. \& Schaufeli, W. B. (2016). Can job crafting reduce job boredom and increase work engagement? A three-year cross-lagged panel study. Journal of Vocational Behavior, 95-96, 11-20. https://doi.org/10.1016/j.jvb.2016.07.001

Hautamäki, L., Ramadan, F., Ranta, P., Haapala, E., \& Suomela-Markkanen, T. (2018). Eläinavusteinen terapia. Katsaus tutkimuskirjallisuuteen ja toimintaan Suomessa.

Hergovich, A., Monshi, B., Semmler, G. \& Zieglmayer, V. (2002). The effects of the presence of a dog in the classroom. Anthrozoös, 15(1), 37-50. https://doi. org/10.2752/089279302786992775

Heuvel, M. van den, Demerouti, E. \& Peeters, M. C. W. (2015). The job crafting intervention: Effects on job resources, self-efficacy, and affective wellbeing. Journal of Occupational and Organizational Psychology, 88(3), 511-532. https://doi.org/10.1111/ joop. 12128 
Jegatheesan, B. (2013). The IAHAIO Definitions for Animal Assisted Intervention and Guidelines for Wellness of Animals Involved in AAl. http://iahaio. org/wp/wp-content/uploads/2018/04/iahaio_wp_ updated-2018-final.pdf

Kahilaniemi, E. (2016). Eläinavusteinen interventio. Helsinki: Voimatassu.

King C, Watters J, Mungre S. (2011). Effect of a timeout session with working animal assisted therapy dogs. Journal of Veterinary Behaviour - Clinical Application and Research, 6(4), 232-238. https://doi. org/10.1016/j.jveb.2011.01.007

Koirat kasvatus- ja kuntoutustyössä ry. (2020). Soveltuvuuskoe. Noudettu osoitteesta http://www. kasvatus-kuntoutuskoirat.fi/yhdistyksen-toiminta/ soveltuvuuskoe/

Kotrschal, K. \& Ortbauer, B. (2003). Behavioral effects of the presence of a dog in a classroom. Anthrozoös, 16(2), 147-159. https://doi. org/10.2752/089279303786992170

Lazazzara, A., Tims, M. \& de Gennaro, D. (2019). The process of reinventing a job: A meta-synthesis of qualitative job crafting research. Journal of Vocational Behavior. https://doi.org/10.1016/J. JVB.2019.01.001

Leppisaari, I. (2020). Digimentorointi osana työelämäläheistä jatkuvan oppimisen ekosysteemiä. Aikuiskasvatus, 40(1), 22-35.

Peral, S. (2016). Exploring the effects of job crafting on subjective well-being amongst South African high school teachers. Journal of Industrial Psychology 42(1), 1-14. https://doi.org/10.13140/ RG.2.1.2800.5525

Poell, R. F., van Dam, K. \& van Den Berg, P. T. (2004). Organising learning in work contexts. Applied Psychology: An Interntional Review, 53(4), 529-540. https://doi.org/10.1111/j.1464-0597.2004.00186.x
Roux, M. C., le, Swartz, L. \& Swart, E. (2014). The Effect of an Animal-Assisted Reading Program on the Reading Rate, Accuracy and Comprehension of Grade 3 Students: A Randomized Control Study. Child and Youth Care Forum, 43(6), 655-673. https:// doi.org/10.1007/s10566-014-9262-1

Soini, T., Pietarinen, J. \& Pyhältö, K. (2008). Pedagoginen hyvinvointi peruskoulun opettajien työssä. Aikuiskasvatus, 28(4), 244-257. http://www.doria.fi/ handle/10024/58333

Tims, M. \& Bakker, A. B. (2010). Job crafting: Towards a new model of individual job redesign. SA Journal of Industrial Psychology, 36(2), 1-9. https://doi. org/10.4102/sajip.v36i2.841

Tims, M., Bakker, A. B. \& Derks, D. (2015). Job crafting and job performance: A longitudinal study. European Journal of Work and Organizational Psychology, 24(6), 914-928. https://doi.org/10.1080/135943 $2 \times .2014 .969245$

Tissen, I., Hergovich, A. \& Spiel, C. (2007). School Based Social-Training with and without Dogs: Evaluation of their Effectiveness. Anthrozoös, 20(4), 365-373.

Tuomi, J. \& Sarajärvi, A. (2018). Laadullinen tutkimus ja sisällön analyysi. Helsinki: Tammi.

Wells, D. L. (2007). The British Psychological Society Domestic dogs and human health: An overview. British Journal of Health Psychology, 12, 145-156. https://doi.org/10.1348/135910706×103284

Wingerden, J., van, Derks, D. \& Bakker, A. B. (2017). The Impact of Personal Resources and Job Crafting Interventions on Work Engagement and Performance. Human Resource Management, 56(1), 51-67. https://doi.org/10.1002/hrm.21758 